\title{
The Difficulties of Vocational High School History Teachers in Developing Historical Learning Evaluation Instrument
}

\author{
Aman \\ Faculty of Social Science \\ Yogyakarta State University \\ Yogyakarta, Indonesia \\ aman@uny.ac.id
}

\begin{abstract}
This research is aimed to know: 1) the difficulties experienced by vocational high school teachers (SMK) in Yogyakarta Special Region in developing historical learning evaluation model, 2) the teachers' efforts in handling difficulties to develop historical learning evaluation model. This research uses descriptive qualitative method. The informants consist of School Principal, Vice School Principal, Students, and SMK history teacher. The research samples are SMK 1 Yogyakarta, SMK 1 Sewon Bantul, SMK 2 Sewon Bantul, and SMK Muhammadyah Wonosari. The data gathering technique uses interview, observation, and document writing techniques. The data validity uses data triangulation technique, method, theory and informant review. The data analysis uses interactive analysis model. The research result indicates that: 1) SMK history teachers find difficulties in developing Lesson Plan and historical learning evaluation especially concerning affective and psychomotor domain, time allocation limitation for implementing comprehensive learning evaluation, and difficulties in combining the three valuation aspects because so far the focus is on cognitive aspect. External factor which influences SMK teachers' difficulties in developing and evaluating history learning concerns school management, the lack of instruction from school party and environment atmosphere; 2) The effort done by teacher to handle difficulties in developing historical learning evaluation method is by exchanging information with other history lesson teachers at MGMP, overcoming time limitation by maximizing time for learning and evaluation, improving learning quality and performing comprehensive evaluation.
\end{abstract}

Keywords-difficulties, teacher, evaluation, historical learning.

\section{INTRODUCTION}

In order to improve the national education quality, the government has done some efforts in developing curriculum and learning material, improving evaluation system, providing book and learning material, improving education facilities, and improving the teachers' competence and school principal's quality. The improvement in some education levels of learning quality also could be an improvement in educational quality. This improvement would be great when all of the system were supported by the education administrator that has good competence. So that, the innovation in educational and learning program can be a requirement that should be done by education administrator.
Classified basic dimensions of education quality as relevant curriculum and relevant materials. [1] These dimensions are also needed by teacher to have skillful management of teaching and knowledge as the content of education in order to facilitate the students' learning.

As defined by Hopkins and Stanley, evaluation as a process of summing up the results of measurements and giving some meaning based on judgment of value. [2] Evaluation can be the achievement of a program, purpose, product or potential approach and the determination of collecting information. Based on the target aspect, evaluation of educational field can be divided into two form, macro evaluation and micro evaluation. The target of macro evaluation is the planned educational program that used to improve education field. On the other hand, micro evaluation is used in the class level where teacher has responsibility in arranging the learning program, while the school has responsibility in evaluating the teacher's approach in teaching. [3] Therefore, one of the important aspects in improving education quality can be done by using the learning program, which is evaluation. To improve the education quality, the evaluation implementation should be done sustainable. Evaluation motivates the students in learning their subject and the teachers in improving their teaching competence profesionally. As proposed by Pedro and Posner teacher should think critically about their practice, develop their ability to examine their own concepts, theories, and beliefs about subject matter and teaching. [4] Based on these reasons, evaluation is not only focussed on the learning assessment, but also the learning input and process.

In educational program context, stated that the achievement of educational program is assessed by the students' learning achievement. [5] On the other hand, evaluation in teaching and learning program needs learning implementation data and goals achievement level. This condition is not only happened in higher education, but also in primary and secondary education. The evaluation of teaching and learning program are based on the aspect of learning assessment. However, the implementation, the quality, and the input of teaching and learning program rarely to be evaluated. The assessment towards the students' 
achievement in learning are limited to the output generally and the outcome also rarely to be evaluated.

The achievement in educational program purpose (the output) is determined by its implementation (the process). And the implementation is also determined by the readiness level in the whole part of educational program as the input. As identified structure of schooling, curriculum, academic standards, learning time, teacher education, the school management, leadership and distribution of responsibilities, professional activities of teachers, and teaching and learning management can be some factors that influence education program and teaching evaluation. [6]

Teaching and learning process is a set of activity in the terms of preparation, implementation, and evaluation. These three aspects are integral unit that cannot be separated. Teaching and learning preparation in the form of unit material covers standard competence, evaluation tools, teaching materials, teaching method, the facility of teaching media, time allocation, setting, funding, expectation, and information. Those are set to support the implementation of teaching and learning process. Students' preparation in physically and mentally can be another important thing in the term of teaching and learning process.

The implementation of teaching and learning process provides interaction among the teacher and the students that expected to have an improvement on the students' competence. The result of learning education depends on the attitude both from teacher and the students. Effective teacher also should teachi in obvious way, usi variation of teaching method and media, have enthusiasm, and use contextual teaching and learning. On the other hand, students should have motivation, seriousness, discipline, curiosity, question, and positive attitude in learning. Effective teacher creates supportive and friendly environment in classroom where students may feel safe, respected, cared and secured. [7] Basically, students need the teacher to have good content of knowledge to help them confidence and enhance their achievement in learning Reynolds et al. [8] The management way of a teacher in learning program will change the thinking of the students towards learning.

The preparation on knowledge and skills for teachers enable them to engage in instruction for the students in learning. It can be the way to have effective proffesional education. [9] In order to have high level on the students behavior, teacher should choose teaching and learning strategy based on reality and experience. The reality can be original or immitation. On the other hand, experience can be in concrete or abstrack form. The process of teaching and learning approach concerns on student centered, reflective learning, active learning, enjoyable dan joyful learning, cooperative learning, quantum learning, learning revolution, dan contextual learning. Multicultural and multiperspective can be the best approach toward the students' motivation in nationalism and national integration. [10]

The evaluation of learning program can be a process to have information in the students' learning achievement.
Therefore, the learning evaluation focusses on the students' achievement, both achievement in the form of process and product. The result information towards the students' achievement will be compared with the learning achievement standard. If the real students' achievement are appropriate with the learning achievement standard, the teaching and learning activity can be categorized as effective learning. Otherwise, if the real students' achievement are not appropriate with the learning achievement standard, the teaching and learning activity categorized as uneffective learning.

This research will be focussed on the evaluation system of vocational high school (SMK) in DIY. The evaluation system is the aspect in deficiency and advantage of vocational high school in DIY. Vocational-technical schools as targeted institution at cultivating students' practical application skills with higher education and vocational technique, where the students from vocationaltechnical schools should place extra emphasis on basic competence and skills required for practice in technical fields. [11] This research gives critically formulation of evaluation system that has been implemented by vocational high school in DIY. The results of this research are expected to give contribution for the school principals and historical teachers regarding to the improvement of the evaluation system. The research problems are identified as 1) what are the vocational high school teachers' difficulties in developing the evaluation of historical learning; and 2) what are the teachers' efforts in developing the evaluation of historical learning.

\section{RESEARCH DISCUSSION}

A. Vocational High School Teacher's Difficulties in Developing Evaluation Model

The complexity of activity component in historical learning made the teachers had difficulties in improving the whole learning components. One of the difficulties was developing the historical learning evaluation. The difficulty aspects are as follows.

1. Difficulties in Developing the Lesson Plan

Generally, vocational high school teachers had problems in developing the lesson plan, especially in formulating KI 1 and KI 2 about spritiual and social aspect and proficiency in affective and pshycomotoric aspect. Teachers' problems in developing the lesson plan could be seen when they still used the previous lesson plan repeatedly. In addition, teachers who did not come from historicl education background could be one of the teachers' problems in developing the lesson plan. Teachers without historical education background teaching and delivering the materials spontaneously only based on the text book. These condition made the teaching and learning process unorganized in a good way.

The certain indicator and learning purpose could be important elements. Unfortunately, most of the vocational high school teachers only foccussed on cognitive aspect. As identified by some theorists and practitioners in teacher 
education that cited, cognitive perspective may engage the students' competence and higher-order thinking skills in knowledge and understanding, such as analysis, synthesis, and evaluation. [12] The arrangement of research purpose in complying students' cogintive and competence and teachers with low competence could be a reason why teachers's still had difficulties in developing the lesson plan.

2. Difficulties in Developing the Assessment Instrument of Historical Subject

In order to know the learning quality, teachers should make an evaluation in the end of the study. Learning assessment could not be done if there were no assessment instrument of lesson plan. The instrument aims to help teachers in recognizing the learning purpose and achievement. The assessment aspects that mentioned in the instrument should cover cognitive, affective, and pshycometric skills. These aspects may resolve to learning deficiencies of unsuccessful students and motivate to successful students in Semerci. [13] The development of assessment instrument standardized with assessment plan of government. This standardized assessment instrument was used by teachers in developing the assessment. Unfortunately, teachers still faced some difficulties in adjusting the assessment instrument that based on the teaching indicators.

Teachers did not have difficulties in regarding to cognitive aspect. However, they still got some difficulties ralated to affective aspect, which was in recording the students' attitude. It was due to a lot number of students and limited time allocation. On the other hand, scoring in affective and psycomotoric aspect did not take criterion guideline because teachers had not arranged the assessment.

3. Difficulties in Delivering the History Subject Material

However, some of vocational high school teachers came from different disciplines and did not have teaching historical education background and had few practice experience. They faced some problems in delivering and developing the teaching materials systematically. These materials should make students to have nationalism and patriotism. On the other hand, another teachers' difficulty was the uncondusive class condition. Students' crowded could make another problem for historical teacher in delivering the teaching materials. The limitation of teaching materials influenced the teachers' competence in delivering the materials because not all of the historical teachers have KTSP curriculum book.

4. Limitation of Time Allocation in Assessment

Teacher also had problems in managing time allocation to have an effective assessment of historical learning. It was due to one of the historical teacher had taught in different school and another teachers taught three different subjects. This condition made the teachers not focuss on what they were responsible for in the term of effective assessment. They only focussed on how much the materials delivered to the students in a large number.

5. Difficulties in Combining Cognitive, Affective, and Pshycometric Aspect
The learning evaluation done by historical teachers were used to assess the students' competence level as the arrangement material of study report. The evaluation in cognitive, affective, and pshycometric aspect used written and aural test consistently and systematically. The cognitive scoring was done by using written and aural test on daily test, middle semester test, and final semester test. On the other hand, the affective scoring was done by scoring the students' attitude in the classroom and the pshycometric assessment was done by giving the students' exercises and discussion. Teachers had difficulties in combining the three assessment aspects, so that they only focused on one aspect, cognitive.

\section{School's Limitation Instruction}

When teachers often got limitation instruction from the school, the school also did not get any difficulties feedback from the historical teachers. The impact of this situation was the principal could not have a good improvement and supervision towards the teachers' difficulties. The less supervision on the teachers' competence in teaching made the decrease of enhancement from the school principal. School administration also plays an essential role in classroom discipline. When there were no commitment among school and teachers, it may reduce opportunities of discipline and increases the behavioral problems inside the classroom in Al-Khatib. [14]

7. Curriculum Change

Indonesian government implements new curriculum for educational process,, which is called Curriculum 2013. This curriculum has been implemented since July 2013. Curriculum 2013 is expected to generate productive, creative, innovative and affective human resources through the competence of attitude, which is spiritual and social; knowledge; and skills in Puskurbuk. [15] The previous curriculum was KTSP developed by each school in accordance with the conditions of the school, regional characteristics, social culture characteristics, and student (Law No. 20 year 2003 on the national education system). The curriculum changing caused teachers got another problem and had to adjust teaching and learning set. The changing curriculum of KTSP to Curriculum 2013 sustained some obstacles on its implementation and teachers got training to adjust themselves to the newest curriculum. Curriculum 2013 was helpful and made teachers had not to arrange lesson plan and evaluation. Teachers were used to have KTSP in teaching and learning process but they got the easiest way in 2013 curriculum for the term of assessment and evaluation.

B. The Way to Help the Teachers' Difficulties in Developing Evaluation Model

In order to develop learning evaluation model of history subject, the teachers should have to:

1. Share Information to Other Teachers in MGMP

Some of historical teachers in DIY had MGMP forum discussion to help them sharing information about suitable teaching method and interesting teaching media 
2. Overcome Time Allocation of Teaching, Learning, and Evaluation

The historical teachers' who had a limitation time in teaching affected the process of teaching and learning could not be maximum. It was due to one teacher should have to teach in two different schools with number of students. In order to develop their competence, teachers should have to manage their time allocation in teaching, assessing, and having evaluation.

3. Enhance Teaching and Learning Quality

Some factors that made low quality in teaching and learning process were teachers had problem in delivering the teaching materials because they did not have historical teaching educational background and the students' difference competence in learning a subject. Input and output quality of the students were influenced each other. This situation made teachers to learn more about the teaching materials that suitable for their students in term of historical subject.

\section{Perform a Comprehensive Evaluation}

In the terms of evaluation, teachers already had good method for cognitive aspect. However, evaluation in affective and psychometric aspect was still low. This condition made teachers realized that they had to develop their motivation and competence to help them in developing affective and psychometric aspect of evaluation.

\section{CONCLUSION}

The difficulties of vocational high school (SMK) historical teachers in developing learning evaluation were: 1) internal and external factors in evaluating historical learning; and 2) the efforts in developing learning evaluation model. The internal factors were the difficulties in developing lesson plan, evaluation instrument of historical subject, evaluation instrument of affective and psychometric aspect; managing time allocation in teaching and learning process; combining the three aspect of cognitive, affective, and pshycometric. In addition, the external factors were the problems in school management, low school supervision, and school environment. On the other hand, teachers should share information to other historical teachers in MGMP about what kind of teaching material and teaching media that suitable for vocational high school students, especially in historical learning; overcome the time limitation in teaching, enhance learning quality and having comprehensive evaluation.

\section{REFERENCES}

[1] Rasheed, Sadig. (2000). Defining quality in education. A paper presented by UNICEF at the meeting of The International Working Group on Education Florence, Italy. New York: NY

[2] Oriondo, L. L. \& Antonio, E. M.D. (1998). Evaluating educational outcomes (Test, measurment and evaluation). Florentino St: Rex Printing Company, Inc.

[3] Mardapi, Djemari. (2011). Pengembangan instrumen dan Kisikisinya. Yogyakarta: Universitas Negeri Yogyakarta.

[4] Rodman, Gloria Jean. (2010). Facilitating the teaching-learning process through the reflective engagement of pre-service teachers. Australian Journal of Teacher Education. Volume 35, Issue 2. (pp. 21-34)

[5] Mardapi, Djemari. (2003). Desain dan penilaian pembelajaran mahasiswa. Lokakarya Sistem Jaminan Mutu Proses Pembelajaran.
[6] Santiago et al. (2009). Teacher evaluation :a conceptual framework and examples of country practices. The OECD-Mexico Workshop.

[7] Ahmad, Iqbal, Rauf, M, et al. (2012). Teachers' perceptions of classroom management, problems and its solutions: case of government secondary schools in chitral, khyber pakhtunkhwa, Pakistan. International Journal of Business and Social Science. Vol. 3 , No. 24

[8] Rubio, Moreno C. (2009). Effective teachers -Professional and personal skills. Revista de la Facultad de Educación de Albacete, 24, 35-46. http://www.uclm.es/ab/educacion/ensayos

[9] Ball, Deborah Loewenberg \& Forzani, Francesca M. (2009). The work of teaching and the challenge for teacher education. Journal of Teacher Education. Vol. 60(5). (pp- 497 -511)

[10] Wiriaatmadja, Rochiati. 2004. Multicultural Perspective in Teaching History to the Chinese Indonesian Studies. Historia: Jurnal Pendidikan Sejarah, No.9 Vol.V

[11] Zhang, Wei. (2009). Issues of practical teaching in vocationaltechnical schools in china and their countermeasures. International Education Studies. Vol. 2 No. 4 (pp. 75-78)

[12] Hackarthornal, Jana., Solomonb, Erin D., Blankmeyerb, Kate., Tennialb, Rachel., \& Garczynskib, Amy. (2011). Learning by Doing: An Empirical Study of Active Teaching Techniques. The Journal of Effective Teaching. Vol. 11 No. 2 (pp. 40-54)

[13] Metin, Mustafa. (2013). Teachers' difficulties in preparation and implementation of performance task. Educational Sciences: Theory \& Practice. Vol. 13, No. 3. (pp. 1664-1673)

[14] Al-amarat, Moh. Salem. (2011). The classroom problems faced teachers at the public schools in tafila province, and proposed solutions. International Journal Education Science. Vol. 3, No. 1 (pp. 37-48)

[15] Retnawati, H., Hadi, S., \&Nugraha, AC. (2016). Vocational high school teachers' difficulties in implementing the assessment in curriculum 2013 in yogyakarta province of indonesia. International Journal of Instruction. Vol.9, No.1 (pp. 1308-1470) 